Piotr Magier*

Lublin

\title{
Do czego pedagogom chrześcijańskim potrzebny jest dialog?
}

Przedmiotem artykułu jest sposób zastosowania kategorii „dialog” w dyskursie dotyczącym pedagogiki chrześcijańskiej. Używając określenia „kategoria dialogu” wskazuję, że nie rozwiązuję problemów przedmiotowych (nie badam zjawisk) oraz że nie konstruuję teorii dialogu. Informuję natomiast, że poruszam się $\mathrm{w}$ obrębie języka ${ }^{1}$. Uszczegóławiając, analizuję przypisywane terminowi „dialog” pojęcia (definicje) oraz funkcje, jakie on posiada na terenie pedagogiki chrześcijańskiej. Przy tak określonym przedmiocie badań prezentowane analizy traktuję jako metaprzedmiotowe.

Prezentowanym badaniom nadaję cel analityczny i sprawozdawczy. Oznacza to przede wszystkim, że unikam projektowania właściwego pojęcia dialogu. Relacjonuję (opisuję) natomiast wybrane problemy związane z obydwoma (tj. definicyjnym i funkcjonalnym) aspektami podjętych badań. Nie aspiruję także do całościowego, systemowego rozwiązania problemu, ale staram się sformułować podstawowe, elementarne i wprowadzające uwagi do-

* Dr Piotr Magier jest pracownikiem Katedry Pedagogiki Ogólnej w Instytucie Pedagogiki Katolickiego Uniwersytetu Lubelskiego Jana Pawła II. Adres: Instytut Pedagogiki KUL, ul. Droga Męczenników Majdanka 70, 20-325 Lublin; e-mail: piomae@kul.pl.

1 Termin „kategoria” rozumiem jako ważny dla danej dziedziny termin wraz z odpowiadającymi mu pojęciami: Andrzej Bronk, „Pojęcie godności człowieka: uwagi metodologa”, w: Antropologiczna pedagogika ogólna, red. Marian Nowak, Piotr Magier, Iwona Szewczak (Lublin: Wydawnictwo KUL, Wydawnictwo Gaudium, 2010), 58. 
tyczące eksplorowanego zakresu przedmiotowego. Uznaję, że kluczowymi aspektami dociekań metaprzedmiotowych są analizy: terminologiczne (etymologiczne oraz pojęciowe), historyczne, strukturalne oraz funkcjonalne ${ }^{2}$.

Jestem także świadomy, że nie poruszam się w problematyce dziewiczej. Przeciwnie, zdaję sobie sprawę, że posiada ona znaczne opracowania zarówno w ramach filozofii, jak i pedagogiki. Niemniej wyrażam nadzieję, że wypowiedziane w tekście uwagi stanowić mogą podstawę dla głębszej, użytecznej dla pedagogów refleksji, zwłaszcza o charakterze metodologicznym.

Ponadto chcę zaznaczyć, że w artykule odwołuję się do polskojęzycznej literatury przedmiotu. Formułowane uogólnienia odnoszę zatem do pedagogiki chrześcijańskiej w Polsce. Strukturę tekstu stanowią: wstęp oraz trzy części merytoryczne: pierwsza poświęcona analizom terminologicznym i definicyjnym, druga zawierająca uwagi dotyczące genezy i procesu historycznych zmian, jakim podlegała kategoria „dialogu” na terenie nauki i chrześcijaństwa, oraz trzecia poświęcona analizie funkcji, jakie pełni ta kategoria w teorii pedagogiki chrześcijańskiej, refleksji uzupełnionej kilkoma uwagami ogólniejszej natury, odnoszącymi się do wybranych kontekstów jej użycia.

\section{Termin i pojęcia dialogu}

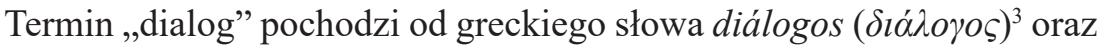
łacińskiego dialogus ${ }^{4}$, które jako formy złożone wywodzą się od podstawowych nazw: diá - thumaczonego jako: „przez”, oraz „logos” - oznaczającego „słowo”. W tym użyciu określenie „dialog” rozumiane jest jako: „komunikacja werbalna”, „komunikacja z użyciem słów”, „konwersacja”. Co ciekawe,

2 Por. tamże, 57-58; Andrzej Bronk, „Wielość nauk i jedność nauki (Stanisława Kamińskiego opcje metodologiczne)", w: Stanisław Kamiński, Nauka i metoda. Pojęcie nauki i klasyfikacja nauk (Lublin: Towarzystwo Naukowe KUL, 1992), 351-353; Andrzej Bronk, Stanisław Majdański, „Metodologia nauk: jej zadania wczoraj i dziś”, w: Metodologia: tradycja i perspektywy, red. Monika Walczak (Lublin: Wydawnictwo KUL, 2010), 11-12.

3 Zygmunt Weclewski, Stownik grecko-polski (Lwów: Księgarnia Samuela Bodeka Ul. Batorego L.20, 1929), 164.

${ }^{4}$ Termin ten thumaczony jest jako: dyskusja, dysputa, rozmowa, dialog, rozważanie. Józef Korpanty, Słownik łacińsko-polski, t. 1: A-H (Warszawa: Wydawnictwo Szkolne PWN, 2001), 544.

5 Por. Krystyna Długosz-Kurczabowa, Stownik Etymologiczny Języka Polskiego (Warszawa: Wydawnictwo Naukowe PWN, 2005), 102-103; https://pl.glosbe.com/el/pl/\%CE- 
w ciągu dziejów badany termin uległ reinterpretacji polegającej na zamianie przedrostka diá na przedrostek di(á), oznaczający „dwa”. W konsekwencji nazwa „dialog” zyskała nową, węższą ${ }^{6}$ treść: ,„łowa dwóch osób”, „rozmowa, zwłaszcza dwóch osób" , „[...] forma komunikacji językowej, w której mówiący i słuchacz wymieniają się nieustannie rolami [...]"8. W tym znaczeniu ,dialog” stanowił także podstawę dla utworzenia analogicznych terminów, jak: „monolog”, „,dekalog”, ,polilog”.

Jak wiele terminów z zakresu humanistyki, również nazwa „dialog” jest wieloznaczna i nieostra. Używana w wielu dziedzinach nauki i kultury oraz różnorodnych kontekstach przyjmuje różne definicje (pojęcia) ${ }^{10}$. Wieloznaczność terminu „dialog” koresponduje także z szeregiem związków frazeologicznych, jakie ten termin tworzy ${ }^{11}$ oraz z mnóstwem synonimów ${ }^{12}$ i antonimów ${ }^{13}$.

\%B4\%CE\%B9\%CE\%AC\%CE\%BB\%CE\%BF\%CE\%B3\%CE\%BF\%CF\%82 (dostęp: 4.09. 2017).

${ }^{6}$ „Dzisiejsze rozumienie terminu «dialog» [...] jest zawężeniem znaczenia klasycznego, w myśl którego w dialogu mogła brać udział większa liczba osób”. Tadeusz Czeżowski, „O dyskusji i dyskutowaniu”, w: Tadeusz Czeżowski, Odczyty Filozoficzne (Toruń-Poznań: Państwowe Wydawnictwo Naukowe, 1969), 191.

${ }^{7}$ Długosz-Kurczabowa, Stownik, 102.

${ }^{8}$ Alicja Nagórko, Marek Łaziński, Hanna Burkhardt, Dystynktywny słownik synonimów (Kraków: Towarzystwo Autorów i Wydawców Prac Naukowych Universitas, 2004), 379.

${ }^{9}$ Długosz-Kurczabowa, Stownik, 102-103.

${ }^{10}$ Przykładowo, prócz wymienionych wyżej pojęć, „dialog” rozumiany jest także jako: „utwór literacki w formie rozmowy”. Lidia Drabik, Aleksandra Kubiak-Sokół, Elżbieta Sobol, Lidia Wiśniakowska, Stownik Języka Polskiego PWN (Warszawa: Wydawnictwo Naukowe PWN, 2007), 137; , ,gatunek, który występował w literaturze staropolskiej, często o przeznaczeniu dramatycznym”. Halina Zgółkowska, Praktyczny słownik współczesnej polszczyzny, t. 8 (Poznań: Wydawnictwo Kurpisz, 1996), 363.

${ }^{11}$ Chodzi chociażby o takie określenia, jak: „dialog polityczny”, „dialog międzypartyjny”, „być otwartym na dialog”, „dialog między państwem a Kościołem”, „,gotowość do dialogu”, ,,warunki dialogu”, ,duch dialogu”, „dialog ekumeniczny”, „otwarty dialog” i inne, por. Bogusław Dunaj, Słownik współczesnego języka polskiego, t. I (Kraków: Wydawnictwo SMS, 2000), 280; Zgółkowska, Praktyczny, 363.

12 Do grona pokreśleń synonimicznych „dialogu” zalicza się takie nazwy jak: „,rozmowa”, „konwersacja”, ,dyskusja”, „,debata”, „,dyskurs”, „rozprawa”, ,argumentacja”, „,dowodzenie”, „uzasadnianie”, „wyjaśnianie” i inne. Wojciech Broniarek, Gdy Ci słowa zabraknie. Słownik synonimów (Brwinów: Haroldson Press, 2010), 102; Piotr Żmigrodzki, Stownik synonimów i antonimów (Warszawa: Wydawnictwo Egmont Polska, 2009), 61-62.

${ }^{13}$ Za antonimy uznawane są takie określenia, jak: „monolog”, ,jazgot”, „milczenie”, „kłótnia”, „sprzeczka”, „konflikt”, „różnica zdań”, „spór”, „utarczka słowna”, „,zwada”, „za- 
„Dialog” zdecydowanie nie jest kategorią neutralną teoretycznie oraz aksjologicznie. Teoretyczny background, jakim obarczony jest ten termin, decyduje tak o jego rozumieniu (definiowaniu), jak również o specyfice użycia. Powszechności nazwy „dialog” towarzyszy proces przypisywania jej konotacji emocjonalnych - najczęściej (zawsze?) dodatnich. Zależności te są na tyle istotne, że wydaje się, iż trudno polemizować z „powagą” dialogu. Okazuje się, że zarówno zjawisko, jak i termin „dialog” stanowią współcześnie swoisty „fetysz"14 znajdujący swe uzasadnienie w specyfice pluralistycznej (postmodernistycznej) kultury ${ }^{15}$. W konsekwencji sytuacja taka zdecydowanie utrudnia rzeczowy i możliwie obiektywny namysł nad tą kategorią, W szczególności sprecyzowanie jej pojęcia i określenie funkcji ${ }^{16}$.

Rzecz jasna, dialog stanowi przedmiot zainteresowania nauki. W jej ramach funkcjonuje nie tylko jako przedmiot badań czy kategoria językowa. Tu doczekał się różnych, istotnych teoretycznie i historycznie ujęć (koncepcji, nurtów). Powszechnie znane są teoretyzacje dialogu na terenie filozofii (filozofia dialogu - m.in. Martin Buber, Franz Rosenzweig, Ferdinad Ebner, Gabriel Marcel, Emmanuel Levinas, Józef Tischner ${ }^{17}$ ) oraz pedagogiki (pedagogika dialogu - m.in. Reinhold Boschki, Janusz Tarnowski, Joanna Rutkowiak, Tadeusz Gadacz, Dorota Jankowska, Jarosław Gara ${ }^{18}$ ).

targ”, ,pyskówka”, por. Andrzej Dąbrówka, Ewa Geller, Słownik antonimów (Warszawa: Wydawnictwo MCR, 1995), 84; Żmigrodzki, Słownik, 62; Jarosław Horowski, „Milczenie jako przestrzeń dialogu", Kwartalnik Pedagogiczny 4/226 (2012): 39-40.

14 „Często słyszymy, że dialog stanowi jedyną skuteczną drogę osiągania prawdy, jest tej prawdy jedynym źródłem, jest też jedyną przestrzenią, w której prawda się pojawia. [...] wytworzona w ten sposób atmosfera bezkrytycznej afirmacji dialogu często sprzyja temu, że spotkania, dialogi, rozmowy, konsultacje, negocjacje, mediacje etc. ulegają fatalnemu zwyrodnieniu”. Józef Dębowski, „«Prawda dialogu» czyli jak uniknąć instrumentalizacji prawdy?”, w: Dialog w kulturze, red. Marek Szulakiewicz, Zbigniew Karpus (Toruń: Wydawnictwo Uniwersytetu Mikołaja Kopernika, 2003), 67-68.

15 Por. Marek Szulakiewicz, „Wprowadzenie”, w: Dialog w kulturze, red. Marek Szulakiewicz, Zbigniew Karpus (Toruń: Wydawnictwo Uniwersytetu Mikołaja Kopernika, 2003), $15-21$.

${ }^{16}$ Zob. Józef Maria Bocheński, Sto zabobonów. Krótki filozoficzny słownik zabobonów (Kraków: Wydawnictwo Philed, 1994), 34-35.

17 Por. Włodzimierz Tyburski, „Dialog w myśleniu i argumentacji filozofów”, w: Dialog w kulturze, red. Marek Szulakiewicz, Zbigniew Karpus (Toruń: Wydawnictwo Uniwersytetu Mikołaja Kopernika, 2003), 26; Krzysztof Skorulski, „Ferdinand Ebner i miejsce filozofii dialogu w myśli katolickiej XX wieku”, Paedagogia Christiana 1/27 (2011): 52-55.

18 Bogusław Milerski, „Pedagogika dialogu jako pedagogika hermeneutyczna”, w: Peda- 
W ramach nauki (filozofii) funkcjonują także istotne dla niniejszego tekstu, analityczne oraz hermeneutyczne ujęcia dialogu. Za klasyczne opracowania w tym zakresie uznać można prace Józefa Marii Bocheńskiego, Romana Ingardena, Tadeusza Czeżowskiego, Władysława Stróżewskiego. Mimo że, jak się wydaje, naukowe określenia „dialogu” zachowują jego „rdzeń pojęciowy" obecny w definicjach słownikowych ${ }^{19}$, to jednak ich istotnym i charakterystycznym elementem jest odniesienie do specyfiki nauki. Wskazują one bowiem szereg warunków, które powinny być spełnione, by w nauce możliwy był (owocny) dialog. Przede wszystkim naukowe analizy dialogu przypisują mu cel poznawczy (zdobycie nowej wiedzy, poznanie rzeczywistości, zrozumienie cudzych lub własnych poglądów), który wymusza szereg specyficznych cech u osób prowadzących dialog, jak: wzajemny szacunek (partnerstwo), rzeczywista (nie pozorna) różnica zdań (koncepcji), znajomość języka oraz teoretycznego backgroundu oponenta, otwartość na argumenty oraz na możliwość zmiany własnych poglądów, pokora polegająca na uznaniu możliwości własnej pomyłki i wreszcie chęć zrozumienia dyskutanta oraz najmniejsza chociaż doza sympatii dla niego i jego poglądów ${ }^{20}$.

O dialogu w nauce nie może być mowy, gdy powyższe warunki nie są spełnione. Za obce dla dialogu naukowego (filozoficznego) uznaje się cele praktyczne oraz polityczne, perswazję bądź apologię, zwłaszcza połączone $\mathrm{z}$ użyciem argumentów ad personam ${ }^{21}$. Jego istocie przeczy także ukrywanie prawdziwych celów, dezinformacja przejawiająca się chociażby w tak zwanej ,nowomowie"22. Podobnie za ,jałowy” poznawczo uznawany jest dialog

gogika dialogu. Dialog jako droga rozumienia i samorozumienia, red. Dorota Jankowska, Marlena Grzelak-Klus (Warszawa: Wydawnictwo Akademii Pedagogiki Specjalnej, 2016), 24-26.

19 Przykładowo: Tadeusz Czeżowski dyskusję (dialog) definiuje jako: „ustną lub pisemną wymianę myśli między dwoma lub więcej uczestnikami, zwykle reprezentującymi przeciwne przekonania lub dążenia, jeżeli jest ona prowadzona w pewnym porządku i zmierza do określonego celu intelektualnego (poznawczego) lub praktycznego”. Czeżowski, „O dyskusji”, 191; Józef Maria Bocheński: „wymianę myśli za pomocą pisma lub mowy”: Józef Maria Bocheński, „O dialogu filozoficznym”, w: Józef Maria Bocheński, Sens życia i inne eseje (Kraków: Wydawnictwo Philed, 1993), 129; Włodzimierz Tyburski jako: „w najprostszej postaci stanowi rozmowę co najmniej dwóch osób”. Tyburski, „Dialog”, 26.

${ }^{20}$ Roman Ingarden, „O dyskusji owocnej słów kilka”, w: Roman Ingarden, Ksiązeczka o człowieku (Kraków: Wydawnictwo Literackie, 1973), 187-189; Bocheński, „O dialogu”, 125, 128-133; Tyburski, „Dialog”, 26-29; Horowski, „Milczenie”, 42-43.

${ }^{21}$ Bocheński, „O dialogu”, 131-132. 
prowadzony przez osoby o zbliżonych poglądach, sytuacja jednostronnego przekazu treści lub znaczna dysproporcja między rozmówcami ${ }^{23}$.

Prócz abnegacji dialogu, także jego absolutyzacja prowadzi do niepożądanych konsekwencji. Chodzi zwłaszcza o relatywizację, subiektywizację i instrumentalizację prawdy. Traktowanie dialogu jako wartości autonomicznej ma prowadzić do zastępowania klasycznego definiowania prawdy jej pojęciami koncyliacyjnymi. Przy czym chodzić może o „wytwarzanie” kompromisu bądź na podstawie opinii specjalistów, bądź na podstawie poglądów forsowanych przez większość. Sytuacja drugiego typu wydaje się „gorsza”, chociażby dlatego, że ocena słuszności wypowiedzi odbywa się tu nie (tylko) na podstawie rzeczowej argumentacji, lecz (również) na podstawie stylu, poprawności gramatycznej czy wręcz jej „kwiecistości”24, z pominięciem odróżnienia ejdetycznej funkcji znaku (słowa, terminu) od jego funkcji operacyjnej ${ }^{25}$.

Na terenie pedagogiki chrześcijańskiej „dialog” stanowi popularną, często przywoływaną kategorię. Powszechność jej użycia nie zawsze jednak koresponduje z precyzją definiowania oraz świadomością jej genezy i różnorodnością funkcji, jakie może ona pełnić. Potrzebę namysłu i ostrożności w stosowaniu „dialogu” uzasadniają zarówno historia nauki oraz chrześcijaństwa, jak i współczesne problemy jego dotyczące. Podobnie jak w dziejach, także obecnie użycie kategorii „dialog” generuje dylematy, istotne zwłaszcza w kontekście dyskusji nad metodologiczną tożsamością pedagogiki chrześcijańskiej.

\section{Uwagi historyczne}

Historycznie i merytorycznie rzecz ujmując, zaznacza się wyraźna różnica między nauką a chrześcijaństwem. Niewątpliwie stanowi ona konsekwencję odmienności cywilizacyjnej oraz różnej natury obu zjawisk. Chodzi zarówno o ich genezę, proces formowania się w obrębie odrębnych kręgów

${ }^{23}$ Por. Bocheński, „O dialogu”, 125-126, 128-134; Józef Maria Bocheński, „W sprawie bożycy”, w: Józef Maria Bocheński, Sens życia i inne eseje (Kraków: Wydawnictwo Philed, 1993), 156; Bocheński, Sto zabobonów, 34; Tyburski, „Dialog”, 26-29; Horowski, „Milczenie", 43.

${ }^{24}$ Dębowski, ,«Prawda dialogu»”, 71-77.

${ }_{25}$ Józef Maria Bocheński, Wspótczesne metody myślenia (Poznań: Wydawnictwo „W drodze", 1992), 49. 
kulturowych, jak szczególnie o różnice istotowe: swoistość przedmiotu, celów, struktury oraz funkcji.

Dialog w nauce pojawił się już u jej zarania, to jest wraz z narodzinami filozofii. Jako specyficzna metoda badań praktykowany był w ramach bodaj wszystkich, ukształtowanych w dziejach koncepcji nauki. Już starożytni filozofowie przyrody, wychodząc w swych refleksjach od obserwacji rzeczywistości oraz poszukując niezmiennej przyczyny zjawisk stosowali dialog (dyskusje) jako metodę prowadzącą do racjonalnego uzasadnienia własnych poglądów (Zenon z Elei). Dialog używany był także przez klasyków humanistyki na terenie filozofii zarówno w celach poznawczych, jak i praktycznych. Jako metoda służąca „dojściu” do prawdy stosowany był chociażby przez Sokratesa i Platona, w celach praktycznych (politycznych), jako sposób przekonującego wyrażania własnych poglądów, wykorzystywali go sofiści ${ }^{26}$.

W czasach nowożytnych dialog również wchodził w zakres kanonu metodologicznego nauki. Specyficzny model dialogu (dyskusji) naukowego wypracowany został w średniowieczu, między innymi dzięki badaniom Augustyna, Anzelma z Canterbury, Piotra Abelarda, Tomasza z Akwinu. Dążąc do racjonalnego uzgodnienia wiedzy filozoficznej z Objawieniem (scholastyka), wymagano rozważenia z całą powagą nie tylko argumentów potwierdzających przyjmowane (własne) stanowisko, lecz również argumentów mu przeciwnych. Wyrazem dialogicznego podejścia do uprawiania nauki w wiekach średnich pozostawały również publiczne dysputy naukowe ${ }^{27}$.

Podobnie w ramach matematycznego przyrodoznawstwa wykorzystywano dialog jako metodę służącą ocenie poprawności stosowanych (konstruowanych) procedur badawczych oraz jako sposób krytyki lawinowo pojawiających się odkryć. Metodologicznym osiągnięciem naukowców szesnastego wieku pozostawała korespondencja naukowa, a następnie upowszechnienie czasopism i instytucji skupiających naukowców, formy wymiany myśli znane i z powodzeniem praktykowane do czasów współczesnych ${ }^{28}$.

W szczególny sposób „dialog” pojmowany był na terenie egzystencjalnych nurtów w filozofii współczesnej (M. Buber, M. Rosenzweig, G. Marcel i inni). Pojmowany był on w ich zakresie nie tylko jako technika badawcza

${ }^{26}$ Stanisław Kamiński, Nauka i metoda. Pojęcie nauki i klasyfikacja nauk (Lublin: Towarzystwo Naukowe KUL, 1992), 48-53; Andrzej Bornk, Agnieszka Salamucha, „Dialog jako droga do prawdy o człowieku", Paedagogia Christiana 1/25 (2010): 13-14.

27 Tamże, 65-72.

${ }_{28}$ Tamże, 87, 96. 
lub typ komunikacji, lecz znacznie szerzej, jako specyficzna postawa, a nawet sposób egzystencji człowieka ${ }^{29}$.

Tradycja judeochrześcijańska uznawana jest za drugie „źródło” promujące dialog w kulturze europejskiej ${ }^{30}$. W jej ramach „dialog” pojawia się jako termin opisujący trzy odmienne typy relacji: odniesienie człowieka względem Boga; relację chrześcijan (wcześniej Żydów) względem wyznawców innych religii, bądź wewnętrznie - wyznań chrześcijańskich względem siebie oraz jako forma (typ) stosunków międzyludzkich („dialog małżeński”, „dialog rodzicielski”). Warto jednak zauważyć, że w każdej z wyżej przytoczonych sytuacji pojęcie dialogu było/jest specyficzne, różniące się względem przyjętego w nauce.

W pierwszym przypadku określenie „dialog” lub bliskoznaczne dla niego nazwy: „rozmowa”, „spotkanie”, używane są w odniesieniu do relacji między człowiekiem a Bogiem. Pojawia się ono wielokrotnie już w Starym Testamencie, natomiast o istotności tej kategorii dla chrześcijaństwa świadczy fakt, że nazywane ono bywa „religią dialogiczną”, to znaczy stale podejmującą dialog z Bogiem ${ }^{31}$. Pojęcie to zawiera przekonanie o zdecydowanej asymetrii podmiotów dialogu (Boga i człowieka) oraz utożsamienie dialogu (spotkania) z pouczeniem, specyficznym „doświadczeniem egzystencjalnym" niejednokrotnie skutkującym nie tylko zmianą poglądów, lecz również przemianą życia (metanoja) ${ }^{32}$.

Drugie pojęcie „dialogu” jest znacznie nowsze, jego geneza sięga bowiem czasów współczesnych. Tradycja starotestamentalna odrzucała możliwość prowadzenia dialogu z poganami zarówno ze względów doktrynalnych, jak i moralnych. Prawda objawiona została jedynie Narodowi Wybranemu, stąd wszystkie inne religie traktowane były jako forma bałwochwalstwa i zazwyczaj zdecydowanie zwalczane. Prócz aspektu doktrynalnego, istotnym elementem uzasadniającym brak możliwości prowadzenia dialogu z ,poganami” były kwestie moralne. Zwyczaje „ludów ościennych” przeczyły religijnie sankcjonowanej moralności praktykowanej przez Żydów.

29 Bocheński, Sto zabobonów, 34-35; Bocheński, „W sprawie”, 156.

30 „Można powiedzieć, że filozofia europejska różnych wieków była świadoma istnienia dialogu. Z jednej strony jego źródłem była filozofia grecka kształtująca dialog w formie intelektualnego dyskursu, z drugiej (...) tradycja biblijno-religijna”. Tyburski, „Dialog”, 29-30.

${ }^{31}$ Bocheński, „W sprawie”, 155-156.

32 Stefan Kunowski, Podstawy współczesnej pedagogiki (Warszawa: Wydawnictwo Salezjańskie, 2001), 98-100; Janusz Tarnowski, „Pedagogika egzystencjalna”, w: Pedagogika. Podręcznik akademicki, t. 1, red. Zbigniew Kwieciński, Bogusław Śliwerski (Warszawa: Wydawnictwo Naukowe PWN, 2008), 255. 
Różnice dotyczyły kwestii fundamentalnych, jak: szacunek dla życia ludzkiego, dezaprobata dla wielu form ekspresji seksualnej (swoboda doboru partnerów, prostytucja, pedofilia, homoseksualizm, masturbacja), uznawanie godności kobiet i dzieci oraz ich istotnej pozycji społecznej ${ }^{33}$. Możliwość podjęcia dialogu (rozmowy) z poganami pojawiała się jedynie w sytuacji ich nawracania się na Religię Mojżeszową ${ }^{34}$.

Ostrożność (niechęć) względem dialogu międzyreligijnego, a później także międzywyznaniowego, przejęło chrześcijaństwo, w tym Kościół katolicki. Podobnie jak w przypadku starożytnego Izraela opierała się ona na przekonaniu o absolutnej słuszności własnej doktryny, niepodważalności przyjętego modelu molarności oraz wyłączności form instytucjonalnego i rytualnego praktykowania wiary. Nieomylność przyjętych rozwiązań niejednokrotnie uzasadniana była w sposób radykalny, a mianowicie traktowano je jako (przynajmniej pożądane) warunki osiągnięcia zbawienia ${ }^{35}$. Chrześcijaństwo już u początku swego istnienia uniwersalizowało własne stanowisko, z rzadka jedynie umożliwiając zwłaszcza zewnętrzny dialog ${ }^{36}$.

Zainteresowanie dialogiem pojawiło się w Kościele katolickim dopiero w okresie Soboru Watykańskiego II. Przed nim Kościół „nie tylko nie praktykował dialogu z innowiercami, lecz w ogóle o nim nie wspominał"37. Za jego propagatora uznaje się papieża Pawła VI, który ideę dialogu spopularyzował w encyklice Ecclesiam suam (6.08.1964). Przy czym dialog

33 Por. Franciszek Adamski, Rodzina. Wymiar społeczno-kulturowy (Kraków: Wydawnictwo Uniwersytetu Jagiellońskiego, 2002), 87-91; Mieczysław Albert Krąpiec, Rozważania o narodzie (Lublin: Fundacja Servire Veritati Instytut Edukacji narodowej, 2004), 12-16.

${ }^{34}$ Prozelityzm, wbrew powszechnej opinii, nie był marginalną cechą judaizmu, por. Piotr Zychowicz, Żydzi. Opowieści niepoprawne politycznie (Poznań: Dom wydawniczy REBIS, 2016), 15-17.

35 Ireneusz Ziemiński, „O możliwości dialogu miedzy religiami kilka banalnych uwag”, w: Dialog w kulturze, red. Marek Szulakiewicz, Zbigniew Karpus (Toruń: Wydawnictwo Uniwersytetu Mikołaja Kopernika, 2003), 229-230; Adamski, Rodzina, 97, 101-108.

36 Wincenty Dudek, „Dialog ekumeniczny”, w: Encyklopedia Katolicka, t. 3, red. Romuald Łukaszczyk, Ludomir Bieńkowski, Feliks Gryglewicz (Lublin: Towarzystwo Naukowe KUL, 1989), 1270-1277; Romuald Łukaszczyk, Ryszard Miś, Henryk Zimoń, „Dialog z religiami pozachrześcijańskimi”, w: Encyklopedia Katolicka, t. 3, red. Romuald Łukaszczyk, Ludomir Bieńkowski, Feliks Gryglewicz (Lublin: Towarzystwo Naukowe KUL, 1989), 1277-1281; Piotr Magier, „Problematyka «wyzwań współczesności» w pedagogice chrześcijańskiej”, Studia Scientifica Facoltatis Paedagogicae Universitas Cahtolica Ružomberok 4 (2012): 83-88.

37 Jerzy Kochanowicz, „Chrześcijański postulat dialogu międzyreligijnego jako wkład w budowanie pokoju”, w: Dialog w kulturze, red. Marek Szulakiewicz, Zbigniew Karpus (Toruń: Wydawnictwo Uniwersytetu Mikołaja Kopernika, 2003), 259. 
traktowany był przez Papieża zarówno jako forma ewangelizacji, jak i jako „odpowiedź” na pluralizm i laicyzację współczesnego świata ${ }^{38}$.

Upowszechnienie się trzeciego pojęcia „dialogu” podobnie przypada na czasy współczesne. Wydaje się, że związane jest ono z rozwojem tak zwanej „teologii rzeczy ziemskich”, popularyzowanej od Soboru Watykańskiego II $^{39}$. Jej wyrazem było opublikowanie szeregu dokumentów duszpasterskich, odnoszących się do różnorodnych zagadnień (problemów) życia katolików, na przykład: małżeństwa i rodziny, pracy i bezrobocia, postępu cywilizacyjnego, edukacji, mediów ${ }^{40}$. Wydaje się, że podobnie jak w ujęciu egzystencjalistów, zawarte w nich pojęcie dialogu jest niezwykle szerokie. Obejmuje bowiem nie tylko proces komunikacji werbalnej, lecz specyficzną postawę, której dominującymi cechami są otwartość, nadzieja, pokora oraz gotowość zrozumienia i przebaczenia ${ }^{41}$.

Zainteresowanie dialogiem na terenie pedagogiki (pedagogii ${ }^{42}$ ) chrześcijańskiej również uznać można za zjawisko współczesne, wcześniej z rzadka tylko pojawiające się na jej terenie. Klasyczne, chrześcijańskie koncepcje wychowawcze wydają się pomijać ten aspekt, skupiając się głównie na wyartykułowaniu własnych zasad doktrynalnych, wychowawczych i dydaktycznych, nierzadko w opozycji do innych stanowisk ${ }^{43}$.

Sądzić można, że zmiana w aspekcie definiowania i opisu funkcji „dialogu" w pedagogice chrześcijańskiej, paralelnie do wewnętrznych zmian w chrześcijaństwie, pozostaje konsekwencją wpływu nań myśli egzysten-

${ }^{38}$ Zbigniew Stachowski, „Miejsce dialogu w kulturze chrześcijańskiej”, w: Dialog w kulturze, red. Marek Szulakiewicz, Zbigniew Karpus (Toruń: Wydawnictwo Uniwersytetu Mikołaja Kopernika, 2003), 241-243.

39 Marian Nowak, Podstawy pedagogiki otwartej. Ujęcie dynamiczne w inspiracji chrześcijańskiej (Lublin: Redakcja Wydawnictw KUL, 1999), 29-30.

${ }^{40}$ Stefan Wołoszyn, Nauki o wychowaniu w Polsce w XX wieku. Próba zarysu encyklopedycznego (Warszawa: Instytut Badań Edukacyjnych, 1993), 86-88.

${ }^{41}$ Adam Szafrański, „Dialog wewnątrzkościelny”, w: Encyklopedia Katolicka, t. 3, red. Romuald Łukaszczyk, Ludomir Bieńkowski, Feliks Gryglewicz (Lublin: Towarzystwo Naukowe KUL, 1989), 1266-1267.

${ }^{42}$ Odróżniam znaczeniowo pedagogikę od pedagogii, uznając, że pedagogika to nauka o wychowaniu, natomiast pedagogia to osadzona teoretycznie praktyka wychowania. Piotr Magier, „Pedagogia”, w: Encyklopedia Katolicka, t. 15, red. Edward Gigilewicz (Lublin: Towarzystwo Naukowe KUL, 2011), 185-186. W odniesieniu do chrześcijaństwa zdecydowanie starsza jest pedagogia, której początki sięgają początków chrześcijaństwa. Józef Wilk, Pedagogika rodziny. Zagadnienia wybrane (Lublin: Episteme, 2016), 24-36.

${ }^{43}$ Por. Wołoszyn, Nauki o wychowaniu, 85-86. 
cjalnej $^{44}$. Definiowanie tego terminu jest zbieżne z propozycjami filozofów egzystencjalnych, a więc ujmowane jest jako specyficzna postawa lub forma (sposób) egzystencji ${ }^{45}$.

\section{Funkcje dialogu w pedagogice chrześcijańskiej}

Pedagogika chrześcijańska, łącząc doktrynę religijną z nauką, przejęła spuściznę obu. Specyficzne trudności teoretyczne i metodologiczne tej dyscypliny/nurtu pozostają przede wszystkim skutkiem „fuzji” nauki i chrześcijaństwa, jaka dokonała się na jej terenie ${ }^{46}$. Podstawową z owych trudności wyraża antynomia między otwartością poznawczą a tożsamością doktrynalną. $Z$ jednej strony mamy bowiem do czynienia z nauką akceptującą zmiany teoretyczne ze względu na dążenie do poznania rzeczywistości (m.in. poprzez dialog, dyskusję), z drugiej z religią opierającą się na przeświadczeniu o (wyłącznej) prawdziwości własnej doktryny ${ }^{47}$. Konsekwentna aplikacja „dialogu” na teren religii wprowadza istotną trudność, a mianowicie konieczność uzgodnienia dwóch istotowo różnych celów: poznawczego i tożsamościowego. Przyjęcie jako nadrzędnego celu poznawczego (obowiązującego każdą naukę), wprowadza niebezpieczeństwo utraty tożsamości doktrynalnej, zatarcia różnic między religiami (lub wyznaniami) oraz miedzy religią a światopoglądami niereligijnymi. Traktowanie „dialogu” jako kategorii nadrzędnej grozi relatywizmem lub agnostycyzmem, ewentualnie (pomijając ekskluzywizm i inkluzywizm) świadomą akceptacją doktryn fałszywych ${ }^{48}$.

${ }^{44}$ Kunowski, Podstawy, 96.

45 Tarnowski, „Pedagogika”, 252-255.

46 Zob. np. Katarzyna Olbrycht, „Współczesne obszary pedagogiki chrześcijańskiej”, Paedagogia Christiana 1/31 (2013): 121-135; Marian Nowak, „Tożsamość pedagogiki chrześcijańskiej”, Paedagogia Christiana 1/31 (2013): 25-44; Piotr Magier, „Tożsamość pedagogiki chrześcijańskiej”, w: Pedagogika chrześcijańska. Tradycja, współczesność, nowe wyzwania, red. Jarosław Michalski, Aldona Zakrzewska (Toruń: Wydawnictwo Adam Marszałek, 2010), 336-345.

47 „Religia podsiada nie tylko zespół rytuałów (kult) oraz organizację instytucjonalną (do których jest często redukowana), lecz przede wszystkim doktrynę (prawdy wiary), uznawaną za prawdziwą. Opiera się ona na założeniach realizmu metafizycznego (faktycznym istnieniu Boga) oraz poznawczego, gwarantując jej prawdziwość”. Ziemiński, „O możliwości”, 222-223, 227-228.

48 Tezę o równej prawdziwości i fałszywości wszystkich religii głosi np. John Hick. Za prawdziwe uznaje się tu przekonanie o istnienie Absolutu - „Ostatecznej Rzeczywistości”, 
W konsekwencji problemem jest odpowiedź na pytanie, czy dialog może dotyczyć aspektów doktrynalnych obecnych w teorii pedagogiki chrześcijańskiej. Być może ograniczony on jest (powinien być) jedynie (aż) do zagadnień dotyczących rytualnych oraz instytucjonalnych aspektów wychowania chrześcijańskiego: wymiany doświadczeń związanych ze wspólnotowym oraz indywidualnym przeżywaniem i praktykowaniem własnej wiary ${ }^{49}$.

Prócz wyżej wymienionego, jak sądzę kluczowego problemu otwartość vs tożsamość, namysł nad użyciem kategorii „dialogu” w pedagogice chrześcijańskiej prowokuje jeszcze inne metodologiczne trudności. Chodzi mianowicie o odpowiedź na pytanie: jakiego typu definicję „dialogu” przyjmuje się w ramach tej subdyscypliny, zwłaszcza kiedy mówi się o dialogu człowieka z Bogiem, oraz czy rzeczywiście w tej sytuacji mamy do czynienia z dialogiem. Dialog między człowiekiem a Bogiem charakteryzuje wyraźna dysproporcja. Zarówno w aspekcie bytowym, jak i poznawczym jest ona ewidentna. Trudno uznać, że człowiek może być partnerem dialogu $\mathrm{z}$ Bogiem $^{50}$. Problem ten posiada jeszcze i ten aspekt, że bezpośrednia rozmowa między osobami biorącymi w nim udział: Bogiem i człowiekiem, jest być może możliwa (jak pokazuje Pismo Święte), lecz raczej (współcześnie) rzadka. Dialog tego typu prowadzony jest zazwyczaj nie wprost, nie ,twarzą w twarz" i nie przy użyciu słów ${ }^{51}$. W przypadku analiz pedagogicznych rozważany problem nie ma wyłącznie charakteru teoretycznego, ale również praktyczny. Pociąga on za sobą istotne konsekwencje wychowawcze, na przykład w odniesieniu do nauki modlitwy.

Inna techniczna uwaga dotyczy warunku różnicy poglądów między rozmówcami (dyskutantami, naukowcami). Nie sposób nie dostrzegać, że znaczna część dialogu naukowego prowadzonego przez pedagogów chrześcijańskich odbywa się „,wewnętrznie”, między nimi ${ }^{52}$. Choć oczywiście nie

natomiast niepewne mają być wszystkie próby jej wyjaśnienia. Ziemiński, „O możliwości”, 229-233.

49 Tamże, 235-238.

50 „Tradycja biblijno-religijna opiera się na pewnej asymetrii - pozycja człowieka jako istoty autonomicznej jest znacznie niższa od Absolutu. Człowiek funkcjonuje jako dziecko Boże z istoty swej nastawione na słuchanie głosu Pana. W relacji człowiek - Bóg dialog przekształca się w spotkanie, a filozofia dialogu w filozofię spotkania”. Tyburski, „Dialog”, 29-30.

${ }^{51}$ Bocheński, „W sprawie”, 155-157.

${ }^{52}$ Bogusław Śliwerski dostrzega, że dyskusja w ramach pedagogiki nie jest zjawiskiem powszechnym. Bogusław Śliwerski, „W odpowiedzi Zbigniewowi Barcińskiemu na jego uwagi odnośnie do mojej książki Pedagogika dziecka. Studium Pajdocentryzmu”, Katecheta 9 (2008): 56. 
jest to standardem, dostrzec można, że dyskurs ten cechuje apologia ${ }^{53}$. Rzadko kiedy pojawiają się w jego ramach osoby o odmiennych zapatrywaniach teoretycznych, a zwłaszcza światopoglądowych. Przy całej życzliwości i zrozumieniu dla potrzeby zachowania tożsamości własnego stanowiska, sytuację taką uznać można (trzeba) za istotne zubożenie poznawcze.

W konsekwencji warto postawić pytanie o funkcje „dialogu” w teorii pedagogiki chrześcijańskiej. Jako kategoria językowa (a przypomnę, w tym właśnie aspekcie zajmuję się „dialogiem” w niniejszym tekście) pełnić ona może dwie podstawowe funkcje: poznawczą lub praktyczną ${ }^{54}$. Mimo że w ramach pedagogiki, klasyfikowanej jako nauka humanistyczna, oba cele nie tylko mogą, ale i powinny być realizowane, to jednak bez wątpienia nie powinny być one ze sobą mylone. W innej sytuacji znajdujemy się bowiem, kiedy opisujemy i wyjaśniamy pewne zjawisko, w innej kiedy je oceniamy i projektujemy. W konsekwencji mówiąc o „dialogu” pedagodzy chrześcijańscy mogą badać, dociekać, czym jest dialog, lecz również mogą go postulować, wskazywać, czym on ma (powinien) być.

Kryterialne rozróżnienie obu funkcji nie jest jednak proste. Stosunkowo łatwe jest ich wskazanie jedynie w przypadku badań empirycznych, które zdecydowanie pełnią funkcję poznawczą. Niestety, na terenie pedagogiki chrześcijańskiej nie jest jednak ich wiele. Jeśli natomiast mamy do czynienia $\mathrm{z}$ analizami teoretycznymi (których, jak sądzę, jest tu znacznie więcej) rozróżnienie funkcji poznawczej i praktycznej nie jest już takie oczywiste. Semiotycy zajmujący się językiem pedagogiki podkreślają, że użycie pewnego teoretycznego terminu w funkcji opisowej może być pozorne. Mimo że językowy kontekst wypowiedzi (zdania) wskazuje na opis lub wyjaśnianie, w rzeczywistości służy on postulowaniu zjawiska, jego projektowaniu ${ }^{55}$.

${ }^{53}$ O pewnej (znacznej) hermetyczności dyskusji prowadzonych w ramach pedagogiki chrześcijańskiej świadczą chociażby kluczowe publikacje poświęcone tematyce wychowania chrześcijańskiego. Autorami tekstów w nich publikowanych są przedstawiciele bądź „sympatycy" pedagogiki chrześcijańskiej. Rzadko pojawiają się w nich teksty autorów wobec niej nieprzychylnych czy przynajmniej krytycznych. Por. np. Pedagogika chrześcijańska. Tradycja, współczesność, nowe wyzwania, red. Jarosław Michalski, Aldona Zakrzewska (Toruń: Wydawnictwo Adam Marszałek, 2010); Wychowanie chrześcijańskie. Między tradycja a współczesnością, red. Alina Rynio (Lublin: Wydawnictwo KUL, 2007).

${ }^{54}$ Bronk, „Pojęcie”, 68.

55 Por. tamże, 65-69; Monika Walczak, „Godność człowieka: kategoria opisowa, wartościująca i normatywna", w: Antropologiczna pedagogika ogólna, red. Marian Nowak, Piotr Magier, Iwona Szewczak (Lublin: Wydawnictwo KUL, Wydawnictwo Gaudium, 2010), 76-80. 
Nie przesądzając, z którą sytuacją mamy (częściej) do czynienia w przypadku użycia kategorii „dialog” w pedagogice chrześcijańskiej, warto zwrócić uwagę na konsekwencje tego stanu rzeczy. Po pierwsze, usankcjonowanie pomyłki co do funkcji terminu (znaku) powoduje, że w teorii (pedagogicznej) uznaje się za rzeczywistość treści, które mają charakter jedynie życzeniowy (realnie nie istnieją), co przynajmniej w pewnych wypadkach nosi znamiona ideologizacji. Po drugie, warto pamiętać, że terminy pełniące istotne funkcje wartościujące często mają ubogą lub niejasno określoną treść, ich istotność poznawcza bywa odwrotnie proporcjonalna do wartości praktycznej. W konsekwencji ich użycie wymaga ostrożności i skrupulatnego definiowania ${ }^{56}$.

\section{What Is the Use of the Dialogue for Christian Pedagogues? (Summary)}

The dialogue is one of modern culture's 'fetishes'. It is used as a key to open many doors in different contexts, to justify many theses, especially to convince auditors how noble and true our opinion is. The popularity of the 'dialogue' (as a phenomenon and as a term) causes the problems with defining the exact meaning to this name. The obvious need to have a dialogue and understanding of its essence in this context is seeming, but existing of the dialogue demands to fulfil all the requirements, which usually are not taken into account. Christian pedagogy also refers to the term of the dialogue. The dialogue and its synonyms are widely used in this pedagogic conception. The main issue is what is the aim (what is the function) of the dialogue, both for theory and practice in Christian pedagogy. The question is: whether this term is used for making Christianity more modern, or has it deeper theoretical bases? In particular it concerns keeping self-identity of Christianity in the ground of pedagogy. The article has methatheoretical character. The main aim is to define the term and functions of the dialogue in the context of Christian pedagogy. It is a set of descriptions and explanations of the problem, not a postulate.

Keywords: Christian pedagogy; dialogue; metatheory; doctrinal identity.

${ }^{56}$ Por. Bronk, Salamucha, „Dialog”, 28; Piotr Magier, „O pedagogicznym rozumieniu «dobra dziecka»”, w: Dziecko w przestrzeni życia społecznego, red. Jadwiga Daszykowska, Andrzej Łuczyński (Stalowa Wola: Wydział Zamiejscowy Nauk o Społeczeństwie KUL, 2013), 44. 


\section{Do czego pedagogom chrześcijańskim potrzebny jest dialog? (Streszczenie)}

Dialog jest jednym z „fetyszy” współczesnej kultury Zachodu. Stanowi „termin-wytrych" używany w różnych kontekstach dla uzasadnienia różnorodnych poglądów, zwłaszcza w celu przekonania o szlachetności (słuszności) pewnego stanowiska. Popularność „dialogu” (zarówno jako zjawiska, jak i terminu) powoduje jednak, że trudno wskazać ostre znaczenie (pojęcie) przypisywane tej nazwie. Jest to termin wyraźnie wieloznaczny, a przez to niekryterialny. Oczywistość potrzeby prowadzenia dialogu, jak i rozumienie jego istoty wydaje się w tym kontekście pozorne, natomiast zaistnienie dialogu wymaga wyraźnie spełnienia szeregu wymogów, które powszechnie nie są uwzględniane. Podobnie jak na terenie szeroko pojętej kultury, również pedagogika chrześcijańska odwołuje się do kategorii dialogu. Dialog i jego synonimy są w ramach tej koncepcji pedagogicznej szeroko wykorzystywane. Problemem jest jednak określenie, czemu służy (jakie pełni funkcje) dialog zarówno na poziomie teorii, jak i praktyki pedagogiki chrześcijańskiej: czy wykorzystanie kategorii dialogu traktować można (jedynie) jako przykład ,uwspółcześnienia” chrześcijaństwa, czy posiada ono głębsze podstawy teoretyczne (doktrynalne). W szczególności chodzi o kwestie zachowania chrześcijańskiej tożsamości w ramach pedagogiki. Wystąpienie ma charakter metaprzedmiotowy. Stanowi próbę określenia pojęć i funkcji, jakie kategorii dialogu przypisuje się w ramach pedagogiki chrześcijańskiej. Nie jest ono systematycznym, postulatywnym wykładem koncepcji dialogu, lecz zbiorem opisowych i wyjaśniających uwag dotyczących podjętego problemu.

Słowa kluczowe: pedagogika chrześcijańska; dialog; metateoria; tożsamość doktrynalna.

\section{Bibliografia}

Adamski, Franciszek. Rodzina. Wymiar społeczno-kulturowy. Kraków: Wydawnictwo Uniwersytetu Jagiellońskiego, 2002.

Bocheński, Józef Maria. „O dialogu filozoficznym”. W: Józef Maria Bocheński, Sens życia i inne eseje, 125-135. Kraków: Wydawnictwo Philed, 1993.

Bocheński, Józef Maria. „W sprawie bożycy”. W: Józef Maria Bocheński, Sens życia i inne eseje, 125-135. Kraków: Wydawnictwo Philed, 1993.

Bocheński, Józef Maria. Sto zabobonów. Krótki filozoficzny stownik zabobonów. Kraków: Wydawnictwo Philed, 1994. 
Bocheński, Józef Maria. Współczesne metody myślenia. Poznań: Wydawnictwo „W drodze", 1992.

Broniarek, Wojciech. Gdy Ci słowa zabraknie. Słownik synonimów. Brwinów: Haroldson Press, 2010.

Bronk, Andrzej. „Pojęcie godności człowieka: uwagi metodologa”. W: Antropologiczna pedagogika ogólna, red. Marian Nowak, Piotr Magier, Iwona Szewczak, 57-74. Lublin: Wydawnictwo KUL, Wydawnictwo Gaudium, 2010.

Bornk, Andrzej, Agnieszka Salamucha. „Dialog jako droga do prawdy o człowieku”. Paedagogia Christiana 1/25 (2010): 11-32.

Bronk, Andrzej, Stanisław Majdański. „Metodologia nauk: jej zadania wczoraj i dziś". W: Metodologia: tradycja i perspektywy, red. Monika Walczak, 9-20. Lublin: Wydawnictwo KUL, 2010.

Bronk, Andrzej. ,Wielość nauk i jedność nauki (Stanisława Kamińskiego opcje metodologiczne)". W: Stanisław Kamiński, Nauka i metoda. Pojęcie nauki i klasyfikacja nauk, 345-370. Lublin: Towarzystwo Naukowe KUL, 1992.

Czeżowski, Tadeusz. „O dyskusji i dyskutowaniu”. W: Tadeusz Czeżowski, Odczyty Filozoficzne, 191-196. Toruń-Poznań: Państwowe Wydawnictwo Naukowe, 1969.

Dąbrówka, Andrzej, Ewa Geller. Słownik antonimów. Warszawa: Wydawnictwo MCR, 1995.

Dębowski, Józef. „«Prawda dialogu» czyli jak uniknąć instrumentalizacji prawdy?”. W: Dialog w kulturze, red. Marek Szulakiewicz, Zbigniew Karpus, 67-93. Toruń: Wydawnictwo Uniwersytetu Mikołaja Kopernika, 2003.

Długosz-Kurczabowa, Krystyna. Stownik etymologiczny języka polskiego. Warszawa: PWN, 2005.

Drabik, Lidia, Aleksandra Kubiak-Sokół, Elżbieta Sobol, Lidia Wiśniakowska. Słownik Jezzyka Polskiego PWN. Warszawa: Wydawnictwo Naukowe PWN, 2007.

Dudek, Wincenty. „Dialog ekumeniczny”. W: Encyklopedia Katolicka, t. 3, red. Romuald Łukaszczyk, Ludomir Bieńkowski, Feliks Gryglewicz, 1270-1277. Lublin: Towarzystwo Naukowe KUL, 1989.

Dunaj, Bogusław. Słownik współczesnego języka polskiego. T. I. Kraków: Wydawnictwo SMS, 2000.

Horowski, Jarosław. „Milczenie jako przestrzeń dialogu”. Kwartalnik Pedagogiczny 4/226 (2012): 39-51.

Ingarden, Roman. „O dyskusji owocnej słów kilka”. W: Roman Ingarden, Książeczka o człowieku, 187-189. Kraków: Wydawnictwo Literackie, 1973.

Kamiński, Stanisław. Nauka i metoda. Pojęcie nauki i klasyfikacja nauk. Lublin: Towarzystwo Naukowe KUL, 1992.

Kochanowicz, Jerzy. „Chrześcijański postulat dialogu międzyreligijnego jako wkład w budowanie pokoju". W: Dialog w kulturze, red. Marek Szulakiewicz, Zbi- 
gniew Karpus, 15-21. Toruń: Wydawnictwo Uniwersytetu Mikołaja Kopernika, 2003.

Korpanty, Józef. Slownik łacińsko-polski. T. 1: A-H. Warszawa: Wydawnictwo Szkolne PWN, 2001.

Krąpiec, Mieczysław Albert. Rozważania o narodzie. Lublin: Fundacja Servire Veritati Instytut Edukacji Narodowej, 2004.

Kunowski, Stefan. Podstawy wspótczesnej pedagogiki. Warszawa: Wydawnictwo Salezjańskie, 2001.

Łukaszczyk, Romuald, Ryszard Miś, Henryk Zimoń. „Dialog z religiami pozachrześcijańskimi”. W: Encyklopedia Katolicka, t. 3, red. Romuald Łukaszczyk, Ludomir Bieńkowski, Feliks Gryglewicz, 1277-1281. Lublin: Towarzystwo Naukowe KUL, 1989.

Magier, Piotr. „O pedagogicznym rozumieniu «dobra dziecka»”. W: Dziecko w przestrzeni życia społecznego, red. Jadwiga Daszykowska, Andrzej Łuczyński, $27-$ -50. Stalowa Wola: Wydział Zamiejscowy Nauk o społeczeństwie KUL, 2013.

Magier, Piotr. „Problematyka «wyzwań współczesności» w pedagogice chrześcijańskiej”. Studia Scientifica Facultatis Paedagogicae Universitas Cahtolica Ružomberok 4 (2012): 81-91.

Magier, Piotr. „Tożsamość pedagogiki chrześcijańskiej”. W: Pedagogika chrześcijańska. Tradycja, współczesność, nowe wyzwania, red. Jarosław Michalski, Aldona Zakrzewska, 336-345. Toruń: Wydawnictwo Adam Marszałek, 2010.

Nowak, Marian. Podstawy pedagogiki otwartej. Ujęcie dynamiczne $w$ inspiracji chrześcijańskiej. Lublin: Redakcja Wydawnictw KUL, 1999.

Nowak, Marian. „Tożsamość pedagogiki chrześcijańskiej”. Paedagogia Christiana 1/31 (2013): 25-44.

Milerski Bogusław. „Pedagogika dialogu jako pedagogika hermeneutyczna”. W: Pedagogika dialogu. Dialog jako droga rozumienia i samorozumienia, red. Dorota Jankowska, Marlena Grzelak-Klus, 21-31. Warszawa: Wydawnictwo Akademii Pedagogiki Specjalnej, 2016.

Nagórko, Alicja, Marek Łaziński, Hanna Burkhardt. Dystynktywny słownik synonimów. Kraków: Towarzystwo Autorów i Wydawców Prac Naukowych Universitas, 2004.

Olbrycht, Katarzyna. „Współczesne obszary pedagogiki chrześcijańskiej”. Paedagogia Christiana 1/31 (2013): 121-135.

Pedagogika chrześcijańska. Tradycja, wspótczesność, nowe wyzwania, red. Jarosław Michalski, Aldona Zakrzewska. Toruń: Wydawnictwo Adam Marszałek, 2010.

Skorulski, Krzysztof. „Ferdinand Ebner i miejsce filozofii dialogu w myśli katolickiej XX wieku". Paedagogia Christiana 1/27 (2011): 49-68. 
Stachowski, Zbigniew. „Miejsce dialogu w kulturze chrześcijańskiej”. W: Dialog w kulturze, red. Marek Szulakiewicz, Zbigniew Karpus, 239-251. Toruń: Wydawnictwo Uniwersytetu Mikołaja Kopernika, 2003.

Szafrański, Adam. „Dialog wewnątrzkościelny”. W: Encyklopedia Katolicka, t. 3, red. Romuald Łukaszczyk, Ludomir Bieńkowski, Feliks Gryglewicz, 1262-1270, Lublin: Towarzystwo Naukowe KUL, 1989.

Szulakiewicz, Marek. „Wprowadzenie”. W: Dialog w kulturze, red. Marek Szulakiewicz, Zbigniew Karpus, 15-21. Toruń: Wydawnictwo Uniwersytetu Mikołaja Kopernika 2003.

Śliwerski, Bogusław. „W odpowiedzi Zbigniewowi Barcińskiemu na jego uwagi odnośnie do mojej książki Pedagogika dziecka. Studium Pajdocentryzmu". Katecheta 9 (2008): 56-65.

Tarnowski, Janusz. „Pedagogika egzystencjalna”. W: Pedagogika. Podręcznik akademicki, t. 1, red. Zbigniew Kwieciński, Bogusław Śliwerski, 248-260. Warszawa: Wydawnictwo Naukowe PWN, 2008.

Tyburski, Włodzimierz. „Dialog w myśleniu i argumentacji filozofów”. W: Dialog w kulturze, red. Marek Szulakiewicz, Zbigniew Karpus, 23-39. Toruń: Wydawnictwo Uniwersytetu Mikołaja Kopernika, 2003.

Walczak, Monika. „Godność człowieka: kategoria opisowa, wartościująca i normatywna”. W: Antropologiczna pedagogika ogólna, red. Marian Nowak, Piotr Magier, Iwona Szewczak, 75-85. Lublin: Wydawnictwo KUL, Wydawnictwo Gaudium, 2010.

Weclewski, Zygmunt. Słownik grecko-polski. Lwów: Księgarnia Samuela Bodeka U1. Batorego L.20, 1929.

Wilk, Józef. Pedagogika rodziny. Zagadnienia wybrane. Lublin: Episteme, 2016.

Wołoszyn, Stefan. Nauki o wychowaniu w Polsce w XX wieku. Próba zarysu encyklopedycznego. Warszawa: Instytut Badan Edukacyjnych, 1993.

Wychowanie chrześcijańskie. Między tradycją a wspótczesnościa, red. Alina Rynio. Lublin: Wydawnictwo KUL, 2007.

Zgółkowska, Halina. Praktyczny słownik współczesnej polszczyzny. T. 8. Poznań: Wydawnictwo Kurpisz, 1996.

Ziemiński, Ireneusz. „O możliwości dialogu miedzy religiami kilka banalnych uwag". W: Dialog w kulturze, red. Marek Szulakiewicz, Zbigniew Karpus, 221-238. Toruń: Wydawnictwo Uniwersytetu Mikołaja Kopernika, 2003.

Zychowicz, Piotr. Żydzi. Opowieści niepoprawne politycznie. Poznań: Dom Wydawniczy REBIS, 2016.

Żmigrodzki, Piotr. Stownik synonimów i antonimów. Warszawa: Wydawnictwo Egmont Polska, 2009. 